Effect of Paraquat on Microbial Activities in Soils

C. M. TU AND W. B. BOLLEN

Reprinted from

Weed Research

Vol. 8, No. 1, March 1968

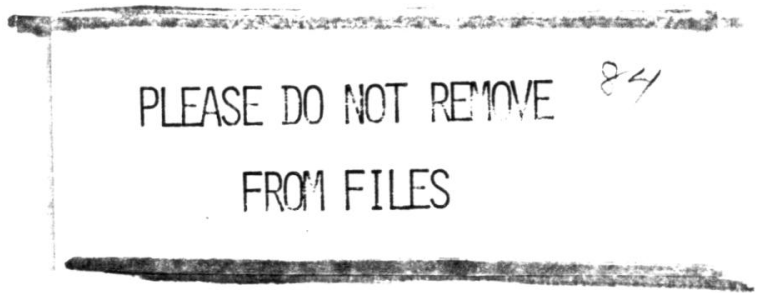

BLACKWELL SCIENTIFIC PUBLICATIONS

OXFORD AND EDINBURGH 

Weed Res. (1968) 8, 28-37.

\title{
EFFECT OF PARAQUAT ON MICROBIAL ACTIVITIES IN SOILS*
}

\author{
C. M. TU AND W. B. BOLLEN† \\ Department of Microbiology, Oregon State University, Corvallis, Oregon, U.S.A.
}

Summary. When paraquat was added to four different soils, nitrification was not appreciably affected but ammonification of soil organic-matter nitrogen was slightly retarded. Carbon dioxide evolution as well as oxygen consumption was used as an index of metabolic activity of soil micro-organisms and paraquat had a stimulatory effect at higher concentrations. Oxidation of added sulphur was slightly depressed. Paraquat decreased both the total mould and bacterial populations in Chehalis silt loam. After 30 days incubation the percentages of Streptomyces and Penicillia were markedly increased by most treatments but were little affected in Chehalis silt clay and Woodburn soils. Except for the temporary suppression of nitrification, paraquat had no significant influence on general microbial activities of importance to soil fertility. Some bimodal effects or toxicity inversions were observed with intermediate concentrations.

Effet du paraquat sur les activités microbiennes dans les sols

Résumé. L'addition de paraquat à quatre sols différents n'a pas affecté la nitrification de façon appréciable mais l'ammonification de l'azote de la matière organique du sol a été légèrement retardée. L'évolution du gaz carbonique et la consommation de l'oxygène ont été utilisées comme un index de l'activité métabolique des micro-organismes du sol. Le paraquat manifesta un effet stimulant aux concentrations les plus élevées. L'oxydation du soufre ajouté a été légèrement ralentie. Le paraquat réduisit les populations totales, à la fois des moisissures et des bactéries dans un limon argileux de Chehalis. Après 30 jours d'incubation les pourcentages des Streptomyces et de Penicillia furent accrus d'une façon marquée par la plupart des traitements, mais furent peu affectés dans le limon argileux de Chehalis et dans les sols de Woodburn. Sauf en ce qui concerne la suppression temporaire de la nitrification, le paraquat n'eut pas d'influence significative sur les activités microbiennes générales qui sont importantes pour la fertilité du sol. Quelques effets bimodaux ou des inversions de toxicité furent observés aux concentrations intermédiaires.

Einfluss von Paraquat auf die Mikroorganismentätigkeit im Boden

Zusammenfassung. Bei Zugabe von Paraquat zu vier verschiedenen Böden wurde die Nitrifikation nicht wesentlich beeinflusst, die Ammonifikation des Stickstoffs aus der organischen Bodensubstanz jedoch leicht gehemmt. Kohlendioxydabgabe und Sauerstoffaufnahme wurden als Mass für die Stoffwechselaktivität der Bodenmikroorganismen herangezogen. Hierbei hatte Paraquat in höheren Konzentrationen eine stimulierende Wirkung. Die Oxydation von Schwefel wurde leicht gehemmt. Durch Paraquat wurde die Zahl von Pilzen und Bakterien in 'Chehalis'-Lehm vermindert. Nach 30-tägiger Inkubationszeit war der Anteil an Streptomyces und Penicillia in den meisten Behandlungen stark erhöht, in 'Chehalis'-Lehm und 'Woodburn'-Böden wurden die Anteile dieser Arten jedoch nur wenig verändert. Ausser der temporären Hemmung der Nitrifikation hatte Paraquat keinen signifikanten Einfluss auf die allgemeinen mikrobiellen Aktivitäten, die für die Bodenfruchtbarkeit von Bedeutung sind. Einige bimodale Effekte oder Toxizitäts-Inversionen wurden bei mittleren Konzentrationen beobachtet.

\section{INTRODUCTION}

Interaction between herbicides and soil micro-organisms may be of practical significance because of the possible inhibition of the microbial activities con-

* Technical Paper No. 2316, Oregon Agricultural Experiment Station, Corvallis. Portion of a thesis submitted by the senior author in partial fulfilment of the requirements for the Ph.D. degree in Microbiology at Oregon State University.

$\dagger$ Respectively, formerly Graduate Assistant (present address: Research Scientist, Research Institute, Canada Department of Agriculture, London, Ontario) and Professor. 

tributing to soil fertility. These organisms, chiefly bacteria, fungi and Streptomyces, occupy a unique position in biological cycles in terrestrial habitats and are essential for plant growth. They decompose root and crop residues, mobilize the reserves of organic nitrogen and phosphorus, carry out transformations involving a change of oxidation state and bring about many other reactions necessary for crop production. Any deleterious influence, even of a temporary nature, could have a serious effect upon crop yields.

A new class of herbicides, the bipyridyl compounds, was first studied by Brian et al. (1958). Kaneshiro \& Zweig (1965) found that diquat (1,1'-ethylene$2,2^{\prime}$-bipyridylium dibromide) at $2 \times 10^{-4}$ moles inhibited both aerobic and anaerobic growth of Rhodospirillum rubrum. With photosynthetic cultures, diquat affected the synthesis of bacteriochlorophyll more than it did cell mass. Bozarth et al. (1965) found that several moulds, bacteria and actinomycetes tolerated relatively high concentrations of paraquat (1,1'-dimethyl-4,4'-bipyridylium dichloride), and that some activity degraded the herbicide. The studies reported here were initiated to determine changes in the microbial activity of soil populations following treatment with different rates of paraquat.

\section{MATERIALS AND METHODS}

The formulation* used contained $2 \mathrm{lb} /$ gal paraquat as di(methylsulphate) and a wetter, or non-ionic spreader activator. $\dagger$ When applied to the soil at the recommended rate of $0.5 \mathrm{lb} / \mathrm{ac}$ paraquat ion, the wetter concentration in $2000000 \mathrm{lb}$ of soil would be approximately $0 \cdot 1 \mathrm{ppm}$.

Solutions of the herbicide were mixed with portions of soil to give concentrations of $0.25 \mathrm{ppm}$, corresponding to the normal field rate, and also concentrations up to $25 \mathrm{ppm}$ to determine the effects of excessive applications. All rates are in terms of the paraquat cation and were calculated for an acre-6.67in., or $2000000 \mathrm{lb}$ soil. Although this laboratory procedure does not exactly correspond to ideal spray practice in the field it does cover the range of concentrations that might result from irregularities in application. Some small areas may receive no herbicide while others may be heavily dosed, as by drip from foliage. In the soil most of the chemical will at first be concentrated on or near the surface but later may diffuse or leach downward, depending upon soil type and climatic conditions. For the kind of laboratory studies reported here a near approach to conditions that could occur in the field can be obtained by a range of treatments, each uniformly mixed with a sample of the soil.

Four different agriculturally important soil types were selected for study. Composite samples of three Willamette Valley soils, Chehalis silty clay loam (CSCL), Chehalis silt loam (CSL) and Woodburn silt loam (WSL) and samples of Delhi sandy loam (DSL) from near Fresno, California, were collected to a depth of 6 in. from fallow ground. The bulk samples were passed through a 10 -mesh sieve. The chemical and physical properties and microbial analyses of the bulk samples are shown in Table 1 .

\footnotetext{
* Supplied by the manufacturer under the Trade Mark 'Gramoxone'.

$\uparrow$ A mixture of alkylarylpolyoxyethylene glycols, free fatty acids and isopropanol, supplied by the manufacturer under the Trade Mark 'X-77'.
} 
Mechanical analyses were determined by the hydrometer method (Bouyou$\cos , 1936)$; $\mathrm{pH}$, with a Beckman model $\mathrm{N}$ glass-electrode $\mathrm{pH}$ meter; and organic matter by dry combustion at $1400^{\circ} \mathrm{C}$ (Allison, Moodie \& Bollen, 1965).

Reagent grade dextrose, peptone, $\left(\mathrm{NH}_{4}\right)_{2} \mathrm{SO}_{4}$, and flour sulphur were employed to determine carbon dioxide evolution, ammonification, nitrification and sulphur oxidation, respectively. The required amount of the liquid was added to sufficient water to mix with $80 \mathrm{~g}$ portions of soil, oven-dry basis, to bring the moisture content to $50 \%$ of the water-holding capacity. The flour sulphur was first mixed with the soil. Paraquat treatments were made by adding the required amounts in dilute solution to give $0.25,0.5,2.5$ and 25 ppm cation when mixed with the soil. Controls, with soil only, were included.

Table 1

Characteristics of soils*

\begin{tabular}{|c|c|c|c|c|}
\hline & CSCL & CSL & $W S L$ & $D S L$ \\
\hline $\begin{array}{l}\text { Chemical analysis } \\
\text { pH } \\
\text { Nitrogen } \\
\mathrm{NH}_{4}^{+}(\mathrm{ppm}) \\
\mathrm{NO}_{2}^{-}(\mathrm{ppm}) \\
\mathrm{NO}_{3}^{-}(\mathrm{ppm}) \\
\mathrm{Kjeldahl}(\%) \\
\text { Organic matter } \uparrow(\%) \\
\text { C/N ratio } \\
\text { Cation-exchange capacity (m-eq/100 g) } \\
\text { Lime requirement (tons/ac) } \\
\text { Phosphate }(\text { as } \mathrm{P})(\mathrm{ppm}) \\
\text { Sulphate }(\text { as } \mathrm{S})(\mathrm{ppm}) \\
\text { Water capacity }(\%) \\
\text { Moisture }(\%) \\
\text { Ash }(\%)\end{array}$ & $\begin{array}{l}6 \cdot 2 \\
38 \\
0 \cdot 32 \\
7 \\
0 \cdot 183 \\
3 \cdot 93 \\
12 \cdot 48 \\
32 \cdot 4 \\
0 \\
36 \\
21 \\
64 \\
21 \cdot 5 \\
95\end{array}$ & $\begin{array}{l}6 \cdot 3 \\
\\
80 \\
0 \cdot 70 \\
16 \\
0 \cdot 112 \\
2 \cdot 55 \\
12 \cdot 65 \\
25 \cdot 3 \\
0 \\
13 \\
5 \\
54 \\
15 \cdot 6 \\
96\end{array}$ & $\begin{array}{l}6 \cdot 1 \\
40 \\
0 \cdot 20 \\
9 \\
0 \cdot 120 \\
2 \cdot 67 \\
12 \cdot 91 \\
16 \cdot 1 \\
1 \\
36 \\
5 \\
42 \\
4 \cdot 0 \\
95\end{array}$ & $\begin{array}{l}6 \cdot 9 \\
21 \\
0 \cdot 03 \\
1 \\
0 \cdot 020 \\
0 \cdot 55 \\
10 \cdot 70 \\
2 \cdot 7 \\
0 \\
23 \\
10 \\
29 \\
0 \cdot 5 \\
99\end{array}$ \\
\hline $\begin{array}{l}\text { Mechanical analysis } \\
\text { Sand }(\%) \\
\text { Silt }(\% \%) \\
\text { Clay }(\%)\end{array}$ & $\begin{array}{l}11 \\
60 \\
30\end{array}$ & $\begin{array}{l}24 \\
51 \\
25\end{array}$ & $\begin{array}{r}9 \\
70 \\
22\end{array}$ & $\begin{array}{l}77 \\
11 \\
12\end{array}$ \\
\hline $\begin{array}{l}\text { Microbial analysis } \\
\text { Moulds (total) (thousands/g soil) } \\
\text { Mucors }(\%) \\
\text { Penicillia }(\%) \\
\text { Aspergilli }(\%)\end{array}$ & $\begin{array}{r}23 \\
17 \\
51 \\
1\end{array}$ & $\begin{array}{r}120 \\
7 \\
31 \\
3\end{array}$ & $\begin{array}{r}250 \\
5 \\
45 \\
9\end{array}$ & $\begin{array}{r}148 \\
6 \\
62 \\
2\end{array}$ \\
\hline $\begin{array}{l}\text { Bacteria (total) (millions/g soil) } \\
\quad \text { Streptomyces }(\%)\end{array}$ & $\begin{array}{r}9 \\
54\end{array}$ & $\begin{array}{l}15 \\
39\end{array}$ & $\begin{array}{l}13 \\
49\end{array}$ & $\begin{array}{l}49 \\
58\end{array}$ \\
\hline
\end{tabular}

* All data expressed on oven-dry basis.

$\dagger$ (Total C by dry combustion $) \div 0 \cdot 58$.

The mixtures and controls were set up in 1-pint milk bottles, which were closed with $\mathrm{Du}$ Pont polyethylene film 1.5 mil thick, and incubated at $28 \pm 1^{\circ} \mathrm{C}$ for appropriate periods. No restoration of distilled water during incubation was required, because the polyethylene film while quite permeable to oxygen, nitrogen and carbon dioxide, had very low permeability to water vapour.

Two replications in duplicate were used in each series of treatments with each rate of herbicide. After 15 and 30 days incubation, samples of the soil were weighed out on an oven-dry basis and added to sufficient distilled water to give $1: 5$ dilutions for determination of nitrate, nitrite, sulphate and $\mathrm{pH}$. 
Harper's (1924) phenoldisulphonic acid method for nitrates was modified by use of ammonium carbonate to remove the excess calcium hydroxide remaining in a 1:5 soil-water extract after clarification. Aliquots of the same extract were used for determination of nitrites by the diazotization method with sulphanilic acid, $\alpha$-naphthylamine hydrochloride and sodium acetate buffer (A.P.H.A., 1955). Sulphate was determined turbidimetrically (A.P.H.A., 1955) in the 1:5 soil-water extracts clarified as for nitrates. Readings were made on a Klett-Summerson photometer with appropriate filters and dilutions, and standard curves were used for calculating concentrations of nitrate and nitrite $\mathrm{N}$, and sulphate sulphur.

Analyses for ammonium N were made by the method of Shrikhande (1941), which employs distillation of the sample with phosphate buffer at $\mathrm{pH} 7 \cdot 4$. Kjeldahl $\mathrm{N}$ was determined by the macro-method, using $10 \mathrm{~g}$ soil samples, $20 \mathrm{~g}$ Hibbard's mixture plus a Hengar selenized granule and $35 \mathrm{ml} \mathrm{H}_{2} \mathrm{SO}_{4}$; digestion was continued for $1 \mathrm{hr}$ after clearing. When cool, the digest was diluted, made alkaline with $70 \% \mathrm{NaOH}$, and $150 \mathrm{ml}$ steam-distilled into $30 \mathrm{ml}$ saturated boric acid solution. The absorbed ammonium was titrated with $\mathrm{N} / 14 \mathrm{H}_{2} \mathrm{SO}_{4}$ after adding bromcresol green-methyl red mixed indicator.

Exchange capacity and exchangeable cations were determined by the ammonium acetate method of Schollenberger \& Simon (1945). Bicarbonatesoluble phosphorus was determined by the method of Olsen et al. (1954).

In the soil respiration studies to show mineralization of organic matter as indicated by carbon dioxide evolution, $80 \mathrm{~g}$ portions of soil, oven-dry basis, were placed in 1-pint milk bottles and treated in duplicate. The herbicide was added at different rates with sufficient water to give $50 \%$ of the water-holding capacity. The bottles were then placed at random in the incubator at $28^{\circ} \mathrm{C}$ and connected to a manifold supplying moisture-saturated $\mathrm{CO}_{2}$-free air at the slight pressure necessary to cause it to bubble slowly through $16 \times 150 \mathrm{~mm}$ test tubes containing $10 \mathrm{ml}$ of approximately $\mathrm{N} / 1 \mathrm{NaOH}$. At intervals of 1, 2, 5, 10, 20 and 30 days incubation the tubes were replaced and the absorbed $\mathrm{CO}_{2}$ was determined by differential titration with a Beckman model $\mathrm{K}$ automatic titrator. Results were graphed as mean values of $\mathrm{CO}_{2}-\mathrm{C}$ evolved per $80 \mathrm{~g}$ of soil (Fig. 1).

The effect of paraquat on general soil microbial activity in Delhi sandy loam was studied by determining oxygen uptake in a Warburg apparatus. Each flask received $4 \mathrm{~g}$ soil moistened with $0.56 \mathrm{ml}$ distilled water. Paraquat was added at rates of $0,0 \cdot 25,2 \cdot 5$ and $25 \mathrm{ppm}$. Treatments with $100 \mathrm{ppm}$ dextrose-C were also made. To absorb $\mathrm{CO}_{2}$, the centre well of each vessel contained $0 \cdot 20$ $\mathrm{ml} 10 \% \mathrm{KOH}$ and a filter paper strip. Optimum oxygen consumption was measured at $30^{\circ} \mathrm{C}$ for $46 \mathrm{hr}$ by stationary manometer. The cumulative values of the oxygen taken up are shown in Fig. 2.

Changes in the soil microflora were determined by analysing samples of soil from the $\mathrm{CO}_{2}$ respiration experiment at 30 days. Soil dilution plate technique was applied by adjusting soil dilutions to give about forty microbial colonies per plate with Martin's (1950) medium for moulds, and about 100 colonies per plate with sodium albuminate agar (Waksman \& Fred, 1922) for bacteria and Streptomyces. All dilutions were plated in triplicate. Counts were made as soon after 
incubation as colonies could be differentiated. The arithmetic means of the triplicate counts were used to calculate numbers of micro-organisms per g soil expressed on an oven-dry basis.

\section{RESULTS AND DISCUSSION}

Each soil had good ammonifying power (Table 2). The influence of paraquat varied, showing no pattern consistent with rate. Effects on ammonification of native organic matter were slightly depressive except in Chehalis silt loam at $2.5 \mathrm{ppm}$ and in Delhi sandy loam soils. Paraquat at all rates had no influence on nitrification of the soil's native organic $\mathrm{N}$ in Chehalis silty clay loam but markedly increased nitrification of ammonium sulphate (Table 3). As evident

Table 2

Ammonification* in different soils after 5 days treatment with paraquat

\begin{tabular}{|c|c|c|c|c|c|c|c|c|c|}
\hline \multicolumn{2}{|c|}{ Treatment } & \multicolumn{2}{|c|}{ CSCL } & \multicolumn{2}{|c|}{$C S L$} & \multicolumn{2}{|c|}{$W S L$} & \multicolumn{2}{|c|}{$D S L$} \\
\hline $\begin{array}{c}\text { Nitrogen } \dagger \\
\text { source }\end{array}$ & $\begin{array}{c}\text { Paraquat } \\
(p p m)\end{array}$ & $p H$ & $\begin{array}{c}\mathrm{NH}_{4}{ }^{+}-\mathcal{N} \\
(p p m)\end{array}$ & $p H$ & $\begin{array}{c}\mathrm{NH}_{4}{ }^{+}-\mathcal{N} \\
(p p m)\end{array}$ & $p H$ & $\begin{array}{c}\mathrm{NH}_{4}{ }^{+}-\mathcal{N} \\
(p p m)\end{array}$ & $p H$ & $\begin{array}{c}\mathrm{NH}_{4}{ }^{+}-\mathcal{N} \\
(p p m)\end{array}$ \\
\hline None & $\begin{array}{r}\text { None } \\
0 \cdot 25 \\
0 \cdot 50 \\
2 \cdot 50 \\
25 \cdot 00\end{array}$ & $\begin{array}{l}6 \cdot 2 \\
6 \cdot 2 \\
6 \cdot 3 \\
6 \cdot 2 \\
-\end{array}$ & $\begin{array}{l}43 \\
13 \\
20 \\
20 \\
-\end{array}$ & $\begin{array}{l}6 \cdot 2 \\
6 \cdot 2 \\
6 \cdot 2 \\
6 \cdot 1 \\
-\end{array}$ & $\begin{array}{l}40 \\
20 \\
20 \\
70 \\
-\end{array}$ & $\begin{array}{l}6 \cdot 0 \\
6 \cdot 0 \\
6 \cdot 0 \\
6 \cdot 1 \\
-\end{array}$ & $\begin{array}{l}23 \\
13 \\
12 \\
15 \\
-\end{array}$ & $\begin{array}{l}6 \cdot 7 \\
6 \cdot 8 \\
6 \cdot 8 \\
6 \cdot 7\end{array}$ & $\begin{array}{r}7 \\
7 \\
-\quad 7 \\
11\end{array}$ \\
\hline Peptone & $\begin{array}{r}\text { None } \\
0 \cdot 25 \\
0 \cdot 50 \\
2 \cdot 50 \\
25.00\end{array}$ & $\begin{array}{l}7 \cdot 2 \\
7 \cdot 3 \\
7 \cdot 2 \\
7 \cdot 2 \\
\end{array}$ & $\begin{array}{l}547 \\
527 \\
620 \\
570 \\
-\end{array}$ & $\begin{array}{l}6 \cdot 8 \\
7 \cdot 5 \\
7 \cdot 6 \\
7 \cdot 7 \\
\end{array}$ & $\begin{array}{l}717 \\
653 \\
657 \\
713 \\
-\end{array}$ & $\begin{array}{l}7 \cdot 1 \\
6 \cdot 9 \\
7 \cdot 2 \\
7 \cdot 1 \\
\end{array}$ & $\begin{array}{l}733 \\
800 \\
663 \\
752 \\
-\end{array}$ & $\begin{array}{l}8.9 \\
8 \cdot 7 \\
8.9 \\
8.9\end{array}$ & $\begin{array}{c}697 \\
713 \\
-\overline{664} \\
703\end{array}$ \\
\hline
\end{tabular}

* Nitrogen liberated as $\mathrm{NH}_{4}^{+}-\mathrm{N}$.

$\uparrow$ Added to give $1000 \mathrm{ppm}$ peptone-N.

from the data for $\mathrm{NH}_{4}^{+}-\mathrm{N}$ and $\mathrm{NO}_{3}^{-}-\mathrm{N}$, ammonification of the native soil $\mathrm{N}$ was extensive. This was not so with the other soils, which showed low nitrifying capacity. Paraquat definitely depressed nitrification in the Chehalis silt loam. Less extensive nitrification of the $\left(\mathrm{NH}_{4}\right)_{2} \mathrm{SO}_{4}$ occurred in the untreated sandy soil and addition of the herbicide increased it slightly. The effect of paraquat on nitrification of the native soil $\mathrm{N}$ during the incubation period for the respiration study also was negligible. The low rate of nitrification based on total nitrogen is not unusual for soils low in organic matter.

The sulphur-oxidizing power of the Chehalis soils and Delhi sandy loam ranged from approximately 12 to $28 \%$ (Table 4). However, in the Woodburn soil it was less than $9 \%$. Generally speaking, paraquat slightly decreased the oxidation of added sulphur, especially in Chehalis silt loam. The effect was less obvious with the Delhi and Woodburn soils. In the silty clay loam paraquat at $0.5 \mathrm{ppm}$ had almost negligible effect while 0.25 and $2.5 \mathrm{ppm}$ were definitely depressive, indicating a possible bimodal or inversion effect.

The effect of paraquat on $0.25,0.5$ and $2.5 \mathrm{ppm}$ on carbon dioxide evolution in the soil respiration experiments is presented in Fig. 1. The influence of the various treatments is shown as changes in total $\mathrm{mg} \mathrm{CO}_{2}-\mathrm{C}$ evolved from $80 \mathrm{~g}$ 
Table 3

Effect of paraquat on nitrification in different soils

\begin{tabular}{|c|c|c|c|c|c|c|c|c|c|c|c|c|c|c|c|c|}
\hline \multicolumn{2}{|c|}{ Treatment } & \multicolumn{4}{|c|}{ CSCL } & \multicolumn{4}{|c|}{$C S L$} & \multicolumn{4}{|c|}{$W S L$} & \multicolumn{3}{|c|}{$D S L$} \\
\hline $\begin{array}{l}\text { Nitrogen* } \\
\text { source }\end{array}$ & $\begin{array}{c}\text { Paraquat } \\
(p p m)\end{array}$ & $p H$ & $\begin{array}{r}15 \\
\mathrm{NH}_{4}^{+} \\
(p p m)\end{array}$ & $\begin{array}{l}\text { lays } \\
\mathrm{NO}_{3}- \\
(p p m)\end{array}$ & $\begin{array}{c}30 \text { days } \dagger \\
\mathrm{NO}_{3}- \\
(\mathrm{ppm})\end{array}$ & $p H$ & $\begin{array}{r}15 \\
\mathrm{NH}_{4}^{+} \\
(\mathrm{ppm})\end{array}$ & $\begin{array}{l}\text { days } \\
\mathrm{NO}_{3}- \\
(\mathrm{ppm})\end{array}$ & $\begin{array}{c}30 \text { days } \dagger \\
\mathrm{NO}_{3}^{-} \\
(p p m)\end{array}$ & $p H$ & $\begin{array}{r}15 \\
\mathrm{NH}_{4}^{+} \\
(p p m)\end{array}$ & $\begin{array}{l}\text { lays } \\
\mathrm{NO}_{3}- \\
(\mathrm{ppm})\end{array}$ & $\begin{array}{c}30 \text { days }{ }^{-} \\
\mathrm{NO}_{3}^{-} \\
(p p m)\end{array}$ & $p H$ & $\begin{array}{r}15 \\
\mathrm{NH}_{4}{ }^{+} \\
(p p m)\end{array}$ & $\begin{array}{l}\text { days } \\
\mathrm{NO}_{3}^{-} \\
(p p m)\end{array}$ \\
\hline None & $\begin{array}{r}\text { None } \\
0 \cdot 25 \\
0 \cdot 50 \\
2 \cdot 50 \\
25 \cdot 00\end{array}$ & $\begin{array}{l}6 \cdot 0 \\
6 \cdot 0 \\
6 \cdot 0 \\
6 \cdot 0 \\
-\end{array}$ & $\begin{array}{l}70 \\
67 \\
87 \\
57 \\
-\end{array}$ & $\begin{array}{r}16 \\
15 \\
21 \\
9 \\
-\end{array}$ & $\begin{array}{l}23 \\
23 \\
33 \\
30 \\
-\end{array}$ & $\begin{array}{l}6 \cdot 1 \\
6 \cdot 2 \\
6 \cdot 2 \\
6 \cdot 2 \\
-\end{array}$ & $\begin{array}{r}8 \\
40 \\
30 \\
28 \\
-\end{array}$ & $\begin{array}{l}25 \\
26 \\
28 \\
25 \\
-\end{array}$ & $\begin{array}{l}29 \\
22 \\
26 \\
29 \\
\end{array}$ & $\begin{array}{l}5 \cdot 9 \\
5 \cdot 9 \\
5 \cdot 9 \\
5 \cdot 9 \\
-\end{array}$ & $\begin{array}{r}7 \\
25 \\
3 \\
4 \\
-\end{array}$ & $\begin{array}{l}26 \\
26 \\
29 \\
20 \\
\end{array}$ & $\begin{array}{l}37 \\
43 \\
44 \\
42 \\
-\end{array}$ & $\begin{array}{l}6 \cdot 7 \\
6 \cdot 7 \\
\frac{6 \cdot 7}{6 \cdot 6}\end{array}$ & $\begin{array}{r}9 \\
14 \\
17 \\
18\end{array}$ & $\begin{array}{r}8 \\
8 \\
7 \\
8\end{array}$ \\
\hline$\left(\mathrm{NH}_{4}\right)_{2} \mathrm{SO}_{4}$ & $\begin{array}{r}\text { None } \\
0 \cdot 25 \\
0 \cdot 50 \\
2 \cdot 50 \\
25 \cdot 00\end{array}$ & $\begin{array}{l}5 \cdot 2 \\
5 \cdot 2 \\
5 \cdot 2 \\
5 \cdot 2 \\
-\end{array}$ & $\begin{array}{l}147 \\
103 \\
120 \\
120 \\
-\end{array}$ & $\begin{array}{r}36 \\
89 \\
153 \\
155 \\
-\end{array}$ & $\begin{array}{l}\overline{-} \\
\overline{-} \\
-\end{array}$ & $\begin{array}{l}5 \cdot 6 \\
5 \cdot 7 \\
5 \cdot 7 \\
5 \cdot 7 \\
-\end{array}$ & $\begin{array}{r}90 \\
123 \\
173 \\
132 \\
-\end{array}$ & $\begin{array}{l}49 \\
14 \\
28 \\
25 \\
-\end{array}$ & $\begin{array}{l}z \\
z \\
z\end{array}$ & $\begin{array}{l}5 \cdot 8 \\
5 \cdot 8 \\
5 \cdot 9 \\
5 \cdot 9 \\
-\end{array}$ & $\begin{array}{l}170 \\
180 \\
170 \\
190 \\
-\end{array}$ & $\begin{array}{l}7 \\
2 \\
4 \\
0 \\
\end{array}$ & $\begin{array}{l}\bar{z} \\
\overline{-} \\
-\end{array}$ & $\begin{array}{l}5 \cdot 4 \\
5 \cdot 6 \\
\overline{5 \cdot 4} \\
5 \cdot 4\end{array}$ & $\begin{array}{l}159 \\
169 \\
\overline{147} \\
165\end{array}$ & $\begin{array}{r}5 \\
9 \\
15 \\
14\end{array}$ \\
\hline
\end{tabular}

$*\left(\mathrm{NH}_{4}\right)_{2} \mathrm{SO}_{4}$ added to give $200 \mathrm{ppm} \mathrm{N}$.

$\uparrow$ Nitrification of native nitrogen source after addition of paraquat. 
soil except for the Warburg study with the Delhi soil in which only $4 \mathrm{~g}$ per flask were used. The measurements of oxygen consumption (Fig. 2) due to the effect of herbicide on the soil microflora give the same general results as the release of $\mathrm{CO}_{2}$. A comparison of the $\mathrm{CO}_{2}$ output and $\mathrm{O}_{2}$ uptake of the untreated soil, and soil plus glucose shows that each of the soil types harboured an active microflora; response of respiratory activity to the glucose addition was vigorous.

Although initially depressive, paraquat increased $\mathrm{CO}_{2}$ evolution from the Chehalis silty clay loam, with $0.5 \mathrm{ppm}$ more effective than the other rates. Similar results were obtained in the other soils, but in the sandy loam it was effective only at the higher rates. After 30 days incubation a pattern was observed between respiration and the oxidation of native organic $\mathrm{N}$ in that additional increases in microbial numbers and activity could result to some extent from the utilization of degradation products and bipyridylium ion.

The changes in $\mathrm{pH}$ induced by paraquat were minor. The other treatments especially sulphur, lowered $\mathrm{pH}$, especially in the lighter soils.

Table 4

Sulphur oxidation in different soils 30 days after treatment with paraquat

\begin{tabular}{|c|c|c|c|c|c|c|c|c|c|}
\hline \multicolumn{2}{|c|}{ Treatment } & \multicolumn{2}{|c|}{$C S C L$} & \multicolumn{2}{|c|}{ CSL } & \multicolumn{2}{|c|}{$W S L$} & \multicolumn{2}{|c|}{$D S L$} \\
\hline Sulphur* & $\begin{array}{c}\text { Paraquat } \\
(p p m)\end{array}$ & & $\begin{array}{c}\mathrm{SO}_{4}^{--}-\mathrm{S} \\
(p p m)\end{array}$ & $p H$ & $\begin{array}{c}\mathrm{SO}_{4}^{--}-S \\
(p p m)\end{array}$ & $p H$ & $\begin{array}{c}\mathrm{SO}_{4}^{--}-S \\
(p p m)\end{array}$ & $p H$ & $\begin{array}{c}S_{4_{4}^{--}-S} \\
(p p m)\end{array}$ \\
\hline None & $\begin{array}{r}\text { None } \\
0.25 \\
0.50 \\
2.50 \\
25.00\end{array}$ & $\begin{array}{l}6 \cdot 1 \\
6 \cdot 3 \\
6 \cdot 3 \\
6 \cdot 3 \\
-\end{array}$ & $\begin{array}{l}33 \\
33 \\
29 \\
43 \\
-\end{array}$ & $\begin{array}{l}6 \cdot 2 \\
6 \cdot 2 \\
6 \cdot 2 \\
6 \cdot 2 \\
-\end{array}$ & $\begin{array}{l}24 \\
28 \\
30 \\
37 \\
-\end{array}$ & $\begin{array}{l}5 \cdot 8 \\
5 \cdot 8 \\
5 \cdot 8 \\
5 \cdot 8 \\
-\end{array}$ & $\begin{array}{l}25 \\
20 \\
20 \\
20 \\
-\end{array}$ & $\begin{array}{l}6 \cdot 6 \\
6 \cdot 6 \\
6 \cdot 5 \\
6 \cdot 5\end{array}$ & $\begin{array}{r}9 \\
9 \\
-10 \\
18\end{array}$ \\
\hline Sulphur & $\begin{array}{r}\text { None } \\
0.25 \\
0.50 \\
2.50 \\
25.00\end{array}$ & $\begin{array}{l}4 \cdot 9 \\
5 \cdot 0 \\
4 \cdot 9 \\
4 \cdot 9 \\
-\end{array}$ & $\begin{array}{l}275 \\
218 \\
266 \\
234 \\
-\end{array}$ & $\begin{array}{l}4 \cdot 7 \\
4 \cdot 8 \\
4 \cdot 7 \\
4 \cdot 6 \\
-\end{array}$ & $\begin{array}{l}219 \\
146 \\
140 \\
131 \\
-\end{array}$ & $\begin{array}{l}5 \cdot 9 \\
5 \cdot 8 \\
5 \cdot 8 \\
5 \cdot 9 \\
-\end{array}$ & $\begin{array}{l}87 \\
59 \\
70 \\
51 \\
-\end{array}$ & $\begin{array}{l}3 \cdot 9 \\
3 \cdot 8 \\
3 \cdot 8 \\
3 \cdot 9\end{array}$ & $\begin{array}{l}116 \\
121 \\
119 \\
116\end{array}$ \\
\hline
\end{tabular}

* Added to give 1000 ppm S.

In the Chehalis silty clay loam paraquat at all rates increased total moulds and percentage of Penicillia while decreasing mucors. Bacteria and Streptomyces were little changed. In Chehalis silt loam, mould counts were decreased but mucors increased at the expense of Penicillia while bacteria and Streptomyces were only slightly influenced.

The stimulating effect of intermediate concentrations, in contrast to the inhibitions obtained with lower as well as higher rates, is similar to results obtained in several investigations with fungicides (Kaars Sijpesteyn \& VanDer Kerk, 1954; Kaars Sijpesteyn, Janssen \& VanDer Kerk, 1956; 1957). Montgomery \& Shaw (1943) found an inversion or polymodal effect with treatments of from 1 to $10000 \mathrm{ppm}$ of thiuram and dithiocarbamate fungicides. Kaars Sijpesteyn \& VanDer Kerk (1954) showed that histidine or imidazole derivatives could antagonize the toxicity of dithiocarbamate to spores of Penicillium italicum and Aspergillus niger when sown on glucose agar containing various concentrations, and that growth inversion zones occurred at certain concen- 


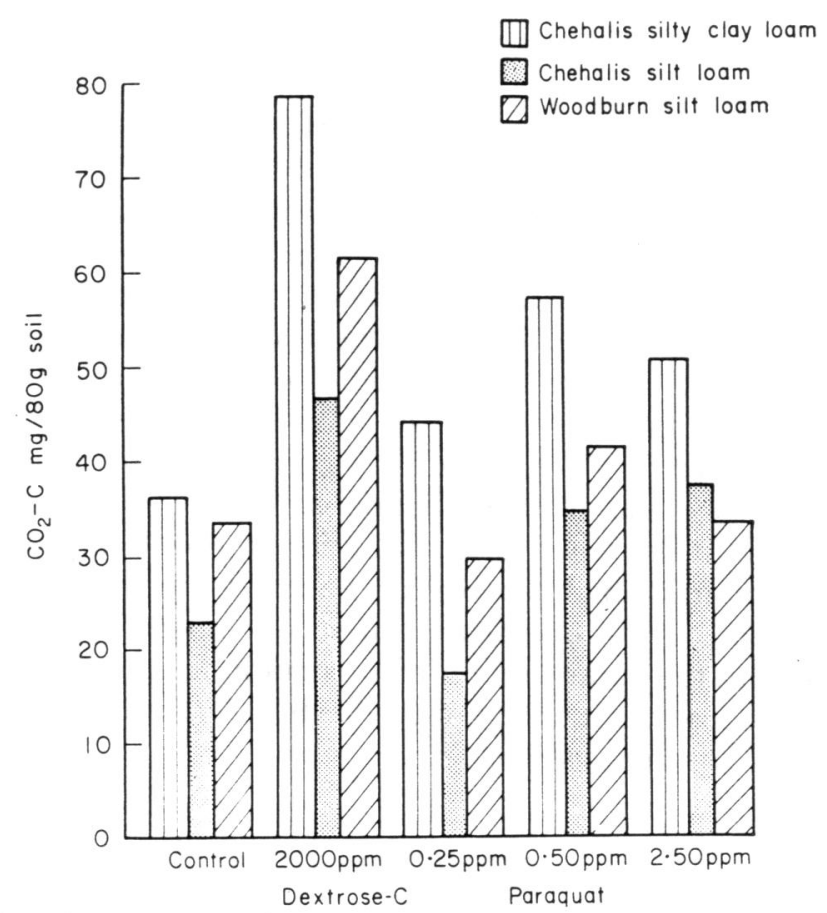

Fig. 1. Effect of paraquat on $\mathrm{CO}_{2}$ evolution from different soils after 30 days incubation.

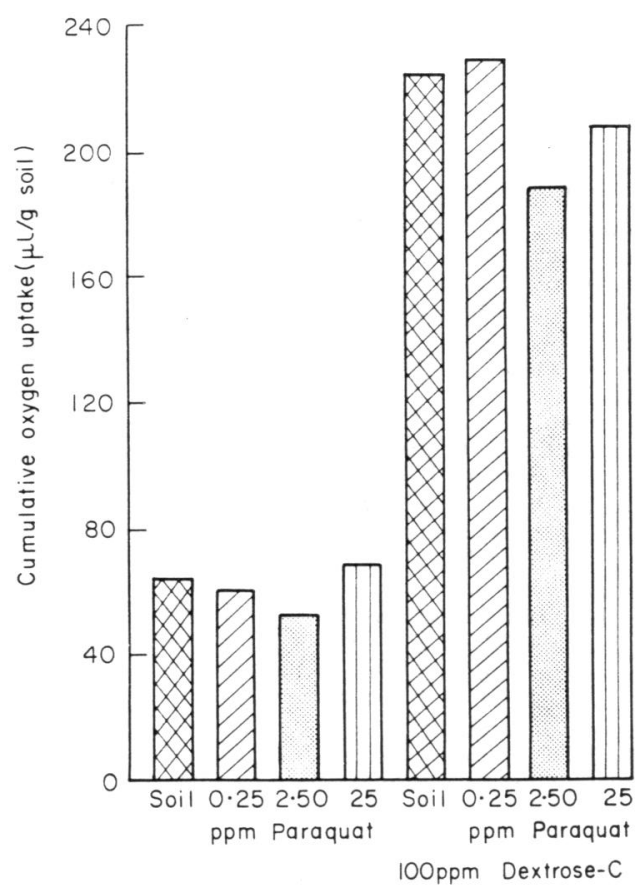

FIG. 2. Effect of paraquat in a manometric study of Delhi sandy loam after $46 \mathrm{hr}$ incubation. 
trations. Kaars Sijpesteyn et al. $(1956 ; 1957)$ also showed that metal ions functioned as chelating agents in the fungitoxic action of dithiocarbamate and as components of the enzyme molecules involved. Metalloenzymes might therefore be competitively inhibited by the bipyridylium ion (Vallee \& Hock, 1955). The observed inversion phenomenon with microbial growth, ammonification, nitrification, sulphur-oxidation and $\mathrm{CO}_{2}$ production could also be due to an antagonistic metabolite of the herbicide as well as to chelating agents.

Possible antagonistic, additive and synergistic effects of wetters and other additives in pesticide formulations should not be overlooked. Preliminary studies with three of the soils previously mentioned (CSCL, CSL, WSL) were made with the wetter ' $\mathrm{X}-77$ ' at 1 and $100 \mathrm{ppm}$, concentrations far in excess of any resulting from usual field applications. Except in one instance (WSL) where at $100 \mathrm{ppm}$ it depressed $\mathrm{CO}_{2}$ evolution, the wetter had only an insignificant influence on microbial numbers and activities in the soil.

From the results of this investigation it is concluded that if paraquat is used in accordance with the manufacturer's instructions for purposes of weed control, there will be no consequent effects of the herbicide on soil micro-organisms and their activities important to soil fertility.

\section{ACKNOWLEDGMENTS}

The authors thank Dr C. R. Harris, Head, Pesticide Section, Research Institute, Canada Department of Agriculture, London, Ontario, for his suggestions during the preparation of this paper.

This investigation was supported in part by the Chevron Chemical Company, Ortho Division, Richmond, California.

\section{REFERENCES}

Allison, L. E., Bollen, W. B. \& Moodie, C. D. (1965) Total carbon. In: Method of Soil Analysis, Pt 2, Chemical and Microbiological Properties (Ed. by C. A. Black et al.), pp. 1346-1366. American Society of Agronomy, Madison, Wisconsin.

American Public Health Association, American Water Works Association, \& Federation of Sewage and Industrial Wastes Associations. (1955) Standard Methods for the Examination of Water and Sewage, 10th edn. American Public Health Association, New York.

Bouyoucos, G. J. (1936) Directions for making mechanical analyses of soils by the hydrometer method. Soil Sci., 42, 225-229.

Bozarth, G. A., Funderburk, H. H., Gurl, E. A. \& Davis, D. E. (1965) Preliminary studies on the degradation of paraquat by soil microorganisms. Proc. 18th sth. Weed Control Conf., 615.

Brian, R. C., Homer, R. F., Stubbs, J. \& Jones, R. L. (1958) A new herbicide: 1, 1'-ethylene-2,2'dipyridylium dibromide. Nature, Lond., 181, 446-447.

Harper, H. J. (1924) The accurate determination of nitrates in soils. Ind. Engng Chem., 16, $180-183$.

KaArs Sijpesteyn, A. \& VanDer Kerk, G. J. M. (1954) Investigations on organic fungicides. IX. The antagonistic action of certain imidazole derivatives and of $\alpha$-keto acids on the fungitoxicity of dimethyldithiocarbamates. Biochim. biophys. Acta, 15, 69-77.

KaArs Sijpesteyn, A., Janssen, M. J. \& VanDer Kerk, G. J. M. (1956) The role of metals in the fungitoxic action of sodium dimethyldithiocarbamate. Biochim. biophys. Acta, 21, 398-399.

Katars Sijpesteyn, A., Janssen, M. J. \& VanDer Kerk, G. J. M. (1957) Investigations on organic fungicides. XI. The role of metals and chelating agents in the fungitoxic action of sodium dimethyldithiocarbamate (NaDDC). Biochim. biophys. Acta, 23, 550-557.

Kaneshiro, T. \& Zweig, G. (1965) Effect of diquat (1,1'-ethylene-2,2'-dipyridylium dibromide) on the photosynthetic growth of Rhodospirillum rubrum. Appl. Microbiol., 13, 939-944.

Martin, J. P. (1950) Use of acid, rose bengal and streptomycin in the plate method for estimating soil fungi. Soil Sci., 69, 215-233.

Montgomery, H.B.S. \& SHaw, H. (1943) Behaviour of thiuram sulphides, etc., in spore germination tests. Nature, Lond., 151, 333. 
Olson, S. R., Cole, C. V., Watanabe, F. S. \& Dean, L. A. (1954) Estimation of available phosphorus in soils by extraction with sodium bicarbonate. Circ. U.S. Dep. Agric., 939.

Schollenberger, C. J. \& Simon, R. H. (1945) Determination of exchange capacity and exchangeable bases in soils-ammonium acetate method. Soil Sci., 59, 13-14.

Shrikhande, J. G. (1941) Determination of ammonical and nitrate nitrogen in decomposed plant material. Ind. Engng Chem. analyt. Edn., 13, 187-188.

Vallee, B. L. \& Hoch, F. L. (1955) Zinc, a component of yeast alcohol dehydrogenase. Proc. natn. Acad. Sci., U.S.A., 41, 327-338.

WaKSMAN, S. A. \& Fred, E. B. (1922) A tentative outline of the plate method for determining the number of microorganisms in the soil. Soil Sci., 14, 27-28.

(Received 4th Fuly 1967) 
